\title{
ASAS-ASAS BANTUAN HUKUM DAN PERAN HAKAM DALAM PENEGAKAN HUKUM: STUDI KRITIS ATAS TAFSIR AL-QURAN SURAT AL-NISÂ' AYAT 35
}

\author{
Didi Kusnadi \\ Mahkamah Agung Republik Indonesia \\ Email:didi.kusnadi@yahoo.com
}

\begin{abstract}
This paper explains the bases of legal aid in Islamic law through a critical study on the concept of hakam reduced from the Quranic interpretation Surah al-Nisâ' verse 35. As a primary source of Islamic law, the Quran is believed guarantying the universal principles of Islamic law that is relevant with law enforcement. It is also implemented practically and comprehensively in the line of the bases of legal aid and developed it into the concept of hakam. Therefore, it can be seen as one of Islamic law contribution within the rule of law in Indonesia through the concept of hakam which can be formed for development of legal aid concept and its application within the law of legal aid in Indonesia.
\end{abstract}

\begin{abstract}
Abstrak
Tulisan ini menjelaskan tentang asas-asas bantuan hukum dalam hukum Islam yang dikaji melalui studi kritis atas konsep hakam yang direduksi dari tafsir al-Quran surat al-Nisâ' ayat 35. Sebagai sumber utama hukum Islam, al-Quran diyakini memuat seperangkat prinsip-prinsip universal yang erat kaitannya dengan penegakan hukum. Prinsip-prinsip hukum tersebut selanjutnya diimplementasikan dalam ranah praktis lebih komprehensif dalam bentuk asas-asas bantuan hukum yang, serta dikembangkan menjadi konsep hakam. Hal tersebut dapat dilihat sebagai salah satu kontribusi hukum Islam melalui perumusan konsep hakam dalam hukum Islam, agar menjadi rujukan bagi pengembangan konsep bantuan hukum dan aplikasinya dalam undangundang bantuan hukum di Indonesia.
\end{abstract}

\section{Kata Kunci: \\ Legal Aid, Islamic Law, Hakam, Law Enforcement}

\section{A. Pendahuluan}

Pada dasarnya, konsep bantuan hukum (the concept of legal aid atau legal service) berkaitan erat dengan ketentuan hukum Islam yang mengajarkan kepada para pemeluknya agar melindungi hak-hak hukum setiap individu, di mana setiap orang sama kedudukannya di depan hukum, dan adanya suatu kewajiban menegakan hukum dan keadilan bagi setiap individu. Ketentuan hukum Islam tersebut menjadi dasar yang paling fundamental bagi adanya bantuan hukum dalam proses penegakan hukum Islam.

Munculnya istilah bantuan hukum sangat dipengaruhi oleh pemikiran hukum Islam tentang konsep hak hukum dalam hak asasi manusia (the concept of legal rights), konsep tentang persamaan di depan hukum (the concept of equality before the law), dan konsep tentang penegakan hukum untuk tujuan keadilan bagi setiap individu (the concept of law enforcement and jutice for all). Ketiga konsep tersebut diasumsikan menjadi kerangka filosofis yang melatarbelakangi adanya konsep bantuan hukum dalam proses penegakan hukum Islam.

Berkenaan dengan hal tersebut, perumusan prinsip-prinsip dan asas-asas bantuan hukum dalam praktik penegakan hukum hendaknya mempertimbangkan tujuan hukum Islam. Adanya pertimbangan-pertimbangan normatif yang terkait dengan peran dan tugas hakim di pengadilan juga turut mendorong pentingnya keberadaan dan peran ban- 
tuan hukum dalam. Oleh karena itu, tulisan ini akan menjelaskan tentang asas-asas bantuan hukum dalam hukum Islam yang dikaji melalui studi kritis atas konsep hakam yang direduksi dari tafsir al-Quran surat al-Nisâ' ayat 35 .

\section{B. Pengacara dan Bantuan Hukum}

Advokat dalam bahasa Inggris merupakan kata benda (noun), berarti orang yang berprofesi memberikan jasa konsultasi hukum dan/atau bantuan hukum baik di dalam maupun di luar pengadilan, yang kini lebih populer dengan sebutan pengacara (lawyer). Sedangkan dalam hukum Islam, advokat berasal dari bahasa Arab, yakni al-mahamî, yang setara maknanya dengan pengacara (lawyer). ${ }^{1}$

Selain itu, dalam bahasa Inggris term advokat juga terkait dengan kata kerja (verb), advocacy yang berarti "suatu pekerjaan dalam bidang konsultasi hukum dan bantuan hukum untuk membantu mereka yang membutuhkan penyelesaian hukum baik di dalam maupun di luar pengadilan". Dalam konteks bahasa Arab, pekerjaan advokat tersebut disebut pula al-mahammah yang setara maknanya dengan kata advocacy. $^{2}$

Untuk memperoleh definisi yang paling jelas, dalam tata hukum Indonesia istilah bantuan hukum dapat ditemukan dalam Bab I Pasal 1 Poin 9 Undang-Undang Nomor 18 Tahun 2003 tentang Advokat bahwa bantuan hukum adalah jasa hukum yang diberikan oleh advokat secara cuma-cuma kepada klien yang tidak mampu. Sedangkan advokat adalah orang yang berprofesi memberi jasa hukum, baik di dalam maupun luar pengadilan yang memenuhi persyaratan berdasarkan undang-undang. Adapun organisasi advokat

Definisi advokat dan bantuan hukum dapat dilihat dalam W.J.S. Poerwadarminta, Kamus Besar Bahasa Indonesia (Jakarta: PT. Ghalia Indonesia. 1992), hlm. 129.

${ }^{2}$ Lihat penjelasan 'Ali Jâr al-Nabî, al-Mahammah wa Afâqa al-Qanûni fî al-Mustaqbal dalam http;//www.brbrnet.net/vb/archive/index.php/t-2106.html. dan lihat pula tulisan Anonimous, Hukm al-Mahammat al-ladzî al-Muhâkimu al-Wadl'iyyat dalam http://www.muslimuzbekistan.net/ar/islam/ fatawa/article.php?ID=8501, diakses tanggal 28 Januari 2015. atau lembaga bantuan hukum adalah organisasi profesi yang didirikan berdasarkan undang-undang. Adapun definisi jasa hukum adalah jasa yang diberikan advokat berupa memberikan konsultasi, menjalankan kuasa, mewa-kili, mendampingi, membela dan melakukan tindakan hukum lain untuk kepentingan hukum klien. ${ }^{3}$

Mengacu kepada beberapa pengertian di atas, penulis berpendapat bahwa access to justice erat kaitannya dengan institusi bantuan hukum. Sedangkan di Indonesia Lembaga Bantuan Hukum (LBH) dikenal sebagai salah satu institusi yang mengarahkan program-programnya pada penguatan aspek permintaan (justice demander) dan aspek pemasokan (justice provider) dalam memberikan jasa konsultasi dan bantuan hukum kepada masyarakat yang tidak mampu. Selain itu, semua bentuk kegiatan pelayanan konsultasi dan bantuan hukum oleh LBH tersebut ditujukan dalam rangka mengimplementasikan prinsip persamaan di depan hukum (equality before the law), pemenuhan hakhak konstitusional semua individu (to pulfill the constitutional rights for all) serta penegakan hukum dan jaminan keadilan (law enforcement and access to justice for all).

\section{Kepengacaraan dan Bantuan Hukum dalam QS. al-Nisâ' Ayat 35}

Dalam al-Quran diketahui banyak sekali ayat yang dijadikan landasan hukum bagi perumusan konsep kepengacaraan dan bantuan hukum. Salah satunya adalah QS. al-Nisâ' ayat 35 yang banyak dijadikan dasar bagi perumusan konsep hakam dalam penegakan hukum.

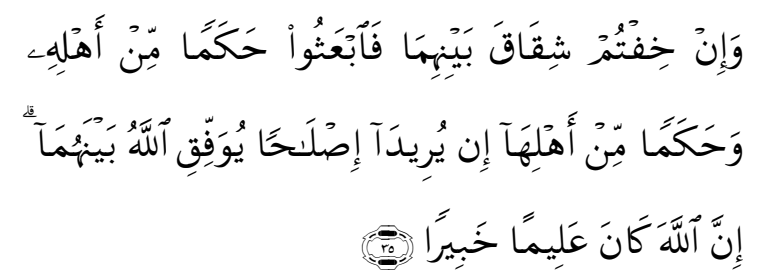

Dan jika kamu khawatirkan ada persengketaan antara keduanya, Maka kirimlah seorang hakam dari keluarga laki-laki dan seorang hakam dari keluarga pe-

3 Lihat dalam Undang-Undang Nomor 18 Tahun 2003 tentang Advokat. 
rempuan. Jika kedua orang hakam itu bermaksud mengadakan perbaikan, niscaya Allah memberi taufik kepada suami-istri itu. Sesungguhnya Allah Maha Mengetahui lagi Maha Mengenal.

Asbâb al-Nuzûl turunnya QS. al-Nisâ' ayat 35 dilatarbelakangi oleh peristiwa yang terjadi di masa Rasulullah SAW. Telah datang seorang perempuan kepada Rasulullah SAW untuk mengadukan tuntutan hak-haknya sebagai istri kepada suaminya. Dalam kisah itu diceritakan bahwa si suami tidak memenuhi kewajiban kepada istrinya sehingga memaksa si istrinya menuntut hak-haknya sebagai istri.

Kasus turunnya ayat tersebut menjadi dasar bagi pemenuhan hak hukum dan keadilan dapat dilakukan oleh tiga jasa hukum, yakni: al-hakâm, al-muftî dan al-mushâlih al'alaih, yang memiliki kesamaana fungsi dengan advokat, pengacara, arbiter, konsultan atau penasehat hukum yang berperan memberikan jasa hukum. Secara umum, fungsi mereka adalah memberikan nasihat atau bantuan jasa hukum kepada para pihak agar mereka saling melaksanakan kewajiban dan mengembalikan haknya kepada pihak lain secara ishlah dan musyawarah sebagaimana dijelaskan dalam QS. al-Nisâ' ayat 35 dan QS. al-Hujurât ayat 59.

Penjelasan di atas juga didukung dengan hadits Nabi yang diriwayatkan oleh Ahmad, Abû Dâwud dan al-Nasai yang menjelaskan pentingnya melakukan ishlah dan musyawarah. Pada gilirannya, kedua ayat al-Quran dan hadits Nabi tersebut menjadi dasar bagi adanya teori ishlah dan teori musyawarah bagi adanya bantuan hukum dalam proses penegakan hukum Islam.

Untuk menjamin persamaan hak hukum dan keadilan, Juhaya S. Praja dalam Filsafat Hukum Islam menjelaskan prinsip-prinsip hukum Islam yang erat kaitannya dengan penegakan hukum, antara lain: Pertama, prinsip tauhid (QS. al-Mâidah: 44-47); Kedua, prinsip keadilan (QS. al-Mâidah: 8); Ketiga, prinsip kebebasan/al-hurriyyah (QS. al-Baqarah: 256); Keempat, prinsip persamaan/al-musâwat (QS. 49:13); Kelima, prinsip 'amar ma'ruf nahyi munkar (QS. al-Nisâ’:10); Keenam, prinsip tolong-menolong/al-ta'âwun (QS. alAn'âm:2); Ketujuh, prinsip musyawarah (QS. al-Syûrâ:38); dan Kedelapan, prinsip toleransi/al-tasâmuh (QS. al-Mumtahanah:8-9). ${ }^{4}$

Selain itu, penerapan prinsip-prinsip penegakan hukum Islam hendaknya juga mengacu kepada kaidah-kidah hukum Islam, "tindakan imam terhadap rakyatnya harus dikaitkan dengan kemaslahatan". Kaidah tersebut didukung dengan kaidah "perbuatan yang mencakup kepentingan orang lain lebih utama daripada hanya kepentingan sendiri". Sehingga tujuan penegakan hukum mengacu kepada kaidah hukum "apa-apa yang tidak bisa kita diambil seluruhnya, maka jangan ditinggalkan seluruhnya". Atas dasar itu, setiap orang adalah pemimpin yang memiliki hak dan kewajiban yang sama dalam hal otoritas hukum, tetapi setiap otoritas hukum itu hendaknya ditujukan untuk kemaslahatan umum (mashlahat al-'ammah). ${ }^{5}$

Demikian halnya dalam penerapan prinsip-prinsip hukum Islam tersebut, peran pengacara dan bantuan hukum dalam penegakan hukum Islam di Pengadilan Agama hendaknya ditujukan untuk keadilan, kebaikan dan kemaslahatan bagi manusia itu sendiri. ${ }^{6}$ Dalam konteks ini, untuk mencapai tujuan keadilan, maka bantuan hukum dalam proses penegakan hukum Islam di Peradilan Agama dapat disandarkan kepada tiga teori, yakni teori konstitusi Hans Kelsen, Teori konstitusi al-Mawdûdî dan teori maslahat Imâm

4 Juhaya S. Praja, Filsafat Hukum Islam (Bandung: UNISBA Press. 1996). Lihat pula Muhammad Muslehudin, Filsafat Hukum Islam dan Pemikiran Orientalis (terj. Yudian Wahyudi Asmin) (Yogyakarta: Tiara Wacana. 1992), hlm. 277-278. Fathurrahman Djamil, Filsafat Hukum Islam Jilid II (Jakarta: Logos Wacana Ilmu. 1997), hlm. 9.

5 Mukhlish Usman, Kaidah-kaidah Ushuliyah dan Fiqhiyyah (Jakarta: Gema Insani Press. 2000), hlm. 49. Asjmuni Rahman, Kaidah-kaidah Fiqih (Qawa'id alFighiyyah) (Jakarta: Bulan Bintang. 1976), hlm. 35. Ibnu Qayyim al-Jawziyyah, I'lâm al-Muwaqqi'în (Beirut: Dâr al-Fikr. t.th.), hlm. 189. dan Al-Syâthibî, al-Muwâfaqât fi Ushûl al-Syarî́ah (Beirut: Dâr al-Kutûb al-'Ilmiyyah. t.th.), Juz II, hlm. 179. dan 'Izzu al-Dîn bin 'Abd al-Salam, Qawâ'id al-Ahkâm fî al-Mashâlih al-Anâm (Beirut: Dâr alFikr. t.th.), hlm. 89 .

6 'Abd al-Karîm Zaydan, Nizhâm al-Qadlâ' fî alSyarî́at al-Islâmiyyah (Baghdad: Matba'ah al-'Ayni. 1983), hlm. 129. 
al-Syâthibî. Ketiga teori ini dapat menjadi applicative theory proses penegakan hukum Islam di Peradilan Agama.

Apabila dikritisi menurut pendapat Hans Kelsen, hukum adalah fakta sosial (social facts) dan norma hukum (legal norm). ${ }^{7}$ Untuk mentransformasikan semua fakta sosial dan norma hukum menjadi suatu hukum, bantuan hukum hendaknya dikodifikasikan secara positif (legal positivism). Menurutnya, disebabkan bantuan hukum itu merupakan fakta sosial (social facts) dan norma hukum (legal norms), maka bantuan hukum itu hendaknya dimuat ke dalam konstitusi negara.

Pendapat Hans Kelsen juga didukung oleh pendapat al-Mawdûdî, yang menyatakan bahwa hierarki hukum Islam tersusun dari pada sumber, prinsip dan asas, metode, kaidah hukum dan produk fikih hingga menjadi undang-undang (qanun). Puncak transformasi hukum Islam menjadi undangundang bantuan hukum adalah ditujukan untuk penegakan hukum Islam di Peradilan Agama. ${ }^{8}$

Adapun relevansinya dengan konsep bantuan hukum dan kepengacaraan dalam hukum Islam tentu tidak dapat dilepaskan dari pemahaman bahwa hukum ini bukan semata-mata sistem hukum yang mengajarkan manusia harus tunduk, taat dan patuh kepada hukum Tuhan, tetapi juga mengatur hubungan antar sesama manusia untuk saling melindungi, menghormati dan menghargai hak-hak hukum orang lain tanpa membeda-bedakan status sosialnya. ${ }^{9}$ Dengan demikian sistem hukum Islam diyakini mengandung muatan pokok-pokok penegakan hukum Islam yang digaransi dalam dua dimensi hukum yakni vertikal dan horizontal. ${ }^{10}$

Dimensi vertikal mengandung pengertian sistem hukum Islam memuat norma-

7 Hans Kelsen, Pure Theory of Law (Lawbook Exchange Ltd., 2005) dan Robert S. Summers, Instrumentalism and American Legal Theory (Ithaca, NY: Cornell University Press. 1982).

8 Abû al-A'lâ al-Mawdûdî, Human Rights in Islam (Leicester: The Islamic Foundation. 1976), hlm. 5-10.

9 Yûsuf Mûsâ, Târîkh al-Fiqh al-Islâmî (Beirut: Dâr al-Maktabah al-Hayat. t.th.), hlm. 10. dan Mannâ' al-Qaththân, al-Tasyrî wa al-Figh fî al-Islâm (Cairo: Mu'assasah al-Risâlah. t.th.), hlm. 14.

10 Muhammad Khidr, al-Islâm wa Huqûq al-Insân (Beirut: Dâr al-Maktabah al-Hayat. 1980), hlm. 18. norma hukum yang erat kaitannya dengan pola hubungan antara manusia dengan Tuhan. Aspek-aspek hukum yang dikaji pada dimensi vertikal merupakan wilayah hukum Islam yang sifatnya ibadah (ta'abbudî). Sedangkan dimensi horizontal mengandung pengertian muatan norma-norma hukum Islam yang berkaitan dengan pola hubungan antara manusia dengan manusia pada ranah hukum perdata dan hukum publik. Aspekaspek hukum yang dikaji pada dimensi horizontal merupakan wilayah hukum Islam yang sifatnya rasional dan empirik, sehingga perlu diuji lebih dalam melalui penalaran akal (ta'aqquîi)."

Demikian pula untuk menjamin tujuan penegakan hukum Islam di Peradilan Agama, maka bantuan hukum tersebut hendaknya ditujukan untuk kemaslahatan. Penulis mengutip teori maslahat Imâm al-Syâthibî, yang banyak menjelaskan teori tujuan hukum Islam (maqâshid al-syarî‘ah) dalam kitabnya al-Muwâfaqât. Menurut teori ini, bantuan hukum dalam proses penegakan hukum Islam di Peradilan Agama hendaknya didasarkan kepada tujuan-tujuan yang bersifat dlarûriyyah, hajjiyah, dan tahsîniyyah - yang berpijak kepada lima tujuan syariat yakni: Pertama, memelihara agama/hifd al-din; Kedua, memelihara jiwa/hifzh al-nafs; Ketiga, memelihara keturunan/hifzh al-nasl; Keempat, memelihara akal/hifzh al-'aql; dan Kelima, memelihara harta/hifzh al-mâl. ${ }^{12}$ Sepanjang bantuan hukum tersebut ditujukan untuk penegakan hukum Islam, maka bantuan hukum itu dapat digunakan oleh para pihak di Peradilan Agama.

\section{Pengacara dan Bantuan Hukum dalam Struktur Keilmuan Hukum Islam}

Secara filosofis, perumusan konsep bantuan hukum dalam proses penegakan hukum Islam di Peradilan Agama, seperti telah dijelaskan sebelumnya berpijak pada tiga teori: Pertama, konsep tentang hak hukum dalam HAM (the concept of legal rights); Kedua,

11 Muhammad Muslehudin, Filsafat Hukum Islam dan Pemikiran Orientalis (terj. Yudian Wahyudi Asmin) (Yogyakarta: Tiara Wacana. 1992), hlm. 277-278.

12 Al-Syâthibî, al-Muwâfaqât fî Ushûl al-Syarî́ah (Beirut: Dâr al-Kutûb al-'`llmiyyah. t.th.), Juz II, hlm. 7. 
konsep tentang persamaan di depan hukum (the concept of equality before the law), dan konsep tentang penegakan hukum untuk tujuan jaminan keadilan bagi setiap individu (the concept of law enforcement and access to jutice for all). Ketiga konsep tersebut diasumsikan menjadi kerangka teoritis bantuan hukum dalam proses penegakan hukum Islam di Peradilan Agama.

Konsep bantuan hukum dalam proses penegakan hukum Islam di Peradilan Agama, salah satunya bisa disandarkan kepada teori hukum alam (lex naturalis atau natural law atau natural rights) dalam filsafat hukum Barat. Teori ini berkembang sejak zaman Romawi dan Yunani hingga abad 19 dan 20, terutama setelah dikenalnya teori hak hukum (legal rights theory) yang bersamaan dengan munculnya gerakan hak asasi manusia (human rights movement). Menurut teori ini, setiap orang diyakini memiliki persamaan hak dan kebebasan sehingga mendorong adanya gerakan bantuan hukum (legal aid movement) di semua negara di dunia tak terkecuali di negara-negara muslim dan khususnya di Indonesia.

Meskipun konsep persamaan hak dalam hukum Barat berbeda filosofinya dengan hukum Islam, akan tetapi secara subtansi hukum Islam telah menggaransi prinsip-prinsip persamaan hak dan penegakan hukum sebagaimana dijelaskan dalam al-Quran, alSunnah dan ljtihad. Di antaranya dalam QS. al-Mâidah ayat 2 dijelaskan kewajiban untuk saling tolong-menolong dalam kebaikan dan takwa. Ayat ini menjadi dasar bagi adanya teori bantuan hukum dalam proses penegakan hukum Islam di Peradilan Agama. Demikian pula dengan hadits Nabi dari Ibnu Qudamah yang diriwayatkan oleh Abu Dâwud menjelaskan pentingnya menegakan hukum melalui persaksian. Hadits ini menjadi dasar bagi adanya teori persaksian dan pembelaan hukum bagi mereka yang sedang berperkara di pengadilan.

Bahkan jika ditelaah lebih dalam, banyak sekali ayat al-Quran dan Sunnah Nabi yang bisa menjadi dasar bagi teori tentang persamaan hak. Misalnya, hak untuk hidup (QS. al-An'âm: 151), hak persamaan derajat (alHujurât: 13), hak memperoleh keadilan (alMâidah: 2 dan 8), hak perlindungan harta dan milik (al-Baqarah: 188) dan hak kebebasan beragama (al-Baqarah: 256 dan Yûnus: 99), serta masih banyak lagi ayat-ayat alQuran yang mengisyaratkan pemenuhan hak-hak manusia.

Kemudian dalam beberapa hadits Nabi juga banyak dijelaskan prinsip-prinsip persamaan hak. Sebagai contoh, prinsip kebebasan dalam hadits yang diriwayatkan oleh Abû Dzar bahwa ia berkata: "Sesungguhnya, saya memaki seseorang kemudian saya mengejek ibunya. Lalu Rasulullah berkata kepada saya; "Wahai Abû Dzar! Bila kamu mengejek ibu orang tadi, maka sesungguhnya dalam dirimu terdapat satu sikap yang mirip dengan tindakan orang jahiliyah". ${ }^{3}$ Dalam hadits lainnya dijelaskan ketika keranda mayat seseorang lewat di depan $\mathrm{Nabi}$, kemudian ada sahabat yang bicara bahwa sesungguhnya mayat itu adalah orang yahudi. Dengan tegas Nabi SAW menjawab; "Tidakkah mayat itu mempunyai kehormatan seorang manusia?". ${ }^{14}$

Oleh karena itu, menurut analisis sementara penulis diketahui bahwa bantuan hukum di Indonesia yang diatur dalam 9 peraturan, antara lain: (a) Undang-Undang Dasar 1945 Pasal 5 (2), 10, 25 (1d), 28 (f, g, h dan i-4); (b) KUH Pidana; (c) KUH Perdata; (d) Undang-Undang Nomor 8 Tahun 1981 tentang KUHAP Pasal 54-56; (e) UndangUndang Nomor 39 Tahun 1999 tentang HAM; (f) Undang-Undang Nomor 26 Tahun 2000 tentang Peradilan HAM; (g) Undang-Undang Nomor 18 Tahun 2003 tentang Advokat Pasal 22 (1-2); (h) Undang-Undang Nomor 4 Tahun 2004 tentang Kekuasaan Kehakiman; dan (i) HIR, belum sepenuhnya mampu mencapai tujuan penegakan hukum Islam sesuai prinsip "access to justice into equality before the law". Dari preposisi tersebut, lahirlah tesis baru yakni teori persamaan hak hukum (equality before the law theory) dan teori hak untuk mendapatkan keadilan (access to justice theory). Kedua teori ini menjadi middle theory bantuan hukum dalam proses penegakan hukum Islam di Peradilan Agama.

13 Lihat Shahîh Muslim Bab Imân Nomor 38 dan Bukhârî Bab Imân Nomor 22.

14 Lihat Shahîh Bukhârî bab Jenazah Nomor 50 dan Shahîh Muslim Bab Jenazah Nomor 81. 


\section{E. Prinsip-prinsip Universal Bantuan Hu- kum dan Kepengacaraan dalam Filsafat Hukum Islam}

Pada dasarnya, konsep bantuan hukum (the concept of legal aid atau legal service) berkaitan erat dengan ketentuan hukum Islam yang mengajarkan kepada para pemeluknya agar melindungi hak-hak hukum setiap individu, di mana setiap orang sama kedudukannya di depan hukum, dan adanya suatu kewajiban menegakan hukum dan keadilan bagi setiap individu. Ketentuan hukum Islam tersebut menjadi dasar yang paling fundamental bagi adanya bantuan hukum dalam proses penegakan hukum Islam. ${ }^{15}$

Berkenaan dengan hal tersebut, munculnya istilah bantuan hukum sangat dipengaruhi oleh pemikiran hukum Islam tentang konsep hak hukum dalam hak asasi manusia (the concept of legal rights), konsep tentang persamaan di depan hukum (the concept of equality before the law), dan konsep tentang penegakan hukum untuk tujuan keadilan bagi setiap individu (the concept of law enforcement and jutice for all). Ketiga konsep tersebut diasumsikan menjadi kerangka filosofis yang melatarbelakangi adanya konsep bantuan hukum dalam proses penegakan hukum Islam. ${ }^{16}$

Di dunia Barat teori persamaan hak hukum (equality before the law theory) dan teori hak untuk mendapatkan keadilan (access to justice theory) didasarkan kepada teori kebebasan (liberal-demokrasi) dan teori konflik untuk pemenuhan kebutuhan materi (materialisme). Teori kebebasan demokrasi diperkenalkan Alan C. Reiter yang berkembang dalam sistem politik dan hukum di negara-negara Eropa, Britania Raya, Amerika Serikat, Canada dan Australia. Teori ini telah berkembang sejak awal abad ke-17 ketika Thomas Hobbes, John Finnis, Thomas Aquinas, Montesquie dan John Locke memper-

15 Imam Mahyudi (Penerjemah), Hak Asasi Manusia Dalam Islam (Jakarta: Rajawali Press. 1996), hlm. 15 .

16 Dalam hukum Islam telah digaransi hak-hak atas hukum dan keadilan bagi setiap individu, masyarakat dan Negara. Lihat penjelasan Abû al-A'lâ alMawdûdî, Human Rights in Islam. hlm. 18. kenalkan ajaran kebebasan dan demokrasi dalam filsafat hukum alam (lex naturalis atau natural law atau natural rights). ${ }^{17}$ Menurut teori ini, setiap orang diyakini memiliki persamaan hak dan kebebasan berdasarkan prinsip persamaan di depan hukum (equality before the law) dan persamaan hak keadilan di depan hukum (access to justice) serta dilakukan melalui advokasi dan bantuan hukum baik di dalam maupun di luar pengadilan.

Selain itu, Karl Heinrich Marx (5 Mei 1818-14 Maret 1883) dikenal sebagai pemikir Barat di abad ke-19 yang menganut ajaran materialisme dan sosialisme, sehingga ia dikenal sebagai "Bapak Komunisme" (The Father of Communism). Dalam karyanya, Des Capital, ia menyebutkan "manifesto komunis" adalah untuk memperjuangkan hak-hak ekonomi kaum buruh (proletariat) dan mengikis habis kekuasaan kaum kaya (Borjuis) melalui gerakan revolusi sosial ekonomi. Salah satu cara yang paling efektif untuk melakukan revolusi itu adalah memediasi "konflik" antara kaum Proletar dan Borjuis. Pendekatan mediasi konflik yang dilakukan oleh Marx ini menjadi dasar bagi upaya bantuan hukum (legal aid) di pengadilan untuk memperjuangkan hak-hak orang lemah dan miskin atas penindasan kaum Borjuis atas dasar tujuan pemenuhan kebutuhan materi. ${ }^{18}$

Sementara itu, bantuan hukum di Indonesia yang diatur dalam Pasal 5 (ayat 1 )

17 Lihat penjelasan lengkap Allan C. Reiter dan Stam, Democracies at War (Princeton, USA: Princeton University Press. 2002). Lihat pula Alan W. Houseman \& Linda E. Perle, Securing Equal Justice for All: A Brief History of Civil Legal Assistance in the United States (US: Center for Law and Social Policy. 2003), hlm. 10-29 dan Helaine M. Barnett, Documenting the Justice Gap in America: The Current Unmet Civil Legal Needs of LowIncome Americans (USA: Legal Services Corporation. 2005), hlm. 4 dan 9 dalam http://en. wikipedia.org/wiki/Liberal_democracy, diakses tanggal 2 Februari 2015.

18 Shlomo Avineri, The Social and Political Thought of Karl Marx (t.t.: Cambridge University Press. 1968), Isaiah Berlin, Karl Marx: His Life and Environment (Britania: Oxford University Press. 1963), G. A. Cohen, Karl Marx's Theory of History: A Defence (Princeton University Press. 1978) David McLellan, Karl Marx: His Life and Thought (Harpercollins, 1978), dan Francis Wheen, Marx's Das Kapital (Atlantic Books. 2006) dalam http://en.wikipedia.org/wiki/Karl_Marx, diakses tanggal 2 Februari 2015. 
Undang-Undang Dasar 1945 disebutkan bahwa setiap orang sama kedudukannya di depan hukum dan keadilan; serta Pasal 1 (poin 9) Undang-Undang Nomor 18 Tahun 2003 tentang Advokat bahwa bantuan hukum adalah jasa hukum yang diberikan oleh Advokat kepada klien yang tidak mampu, ${ }^{19}$ ternyata belum menjadi jaminan bagi penegakan hukum Islam di Peradilan Agama. Padahal upaya Bantuan hukum tersebut ditujukan untuk menjamin hak-hak hukum setiap warga negara dalam memperoleh keadilan di depan hukum.

Untuk menjelaskan prinsip-prinsip penegakan hukum di pengadilan, penulis mengutip penjelasan Juhaya S. Praja dalam Filsafat Hukum Islam bahwa dalam al-Quran sebagai sumber utama hukum Islam - dijelaskan beberapa ayat hukum yang erat kaitannya dengan prinsip-prinsip dan asasasas hukum Islam yang erat kaitannya dengan penegakan hukum dan kewajiban untuk menghormati hak-hak setiap individu dalam kehidupan bermasyarakat, berbangsa dan bernegara. Ayat-ayat hukum itu, merupakan landasan normatif yang memuat prinsip-prinsip dan asas-asas penegakan hukum Islam yang mencakup atas: ${ }^{20}$

1. Prinsip Keesaan Tuhan/al-Tawhîd)

Menurut prinsip ini, manusia memiliki kewajiban tunduk, taat dan patuh kepada Allah dan Rasulnya, serta dilarang mempersekutukan Allah dengan yang lainnya. Ketentuan ini salah satunya tercantum dalam QS. al-Nisâ': 36.

2. Prinsip Keadilan/al-'Adâlah)

Menurut prinsip ini, manusia berkewajiban menegakan hukum-hukum Allah dan

19 Dewasa ini ada suatu kenyataan di masyarakat bahwa bantuan hukum (legal aid atau legal services) dianggap sebagai salah satu bentuk upaya hukum bagi para pencari keadilan (everyone who are looking for justice). Selain itu, dengan segala bentuknya, bantuan hukum merupakan representasi dari akses mendapatkan keadilan (access to justice) dalam konteks semua orang sama kedudukannya di depan hukum (equality before the law). Lihat Adnan Buyung Nasution, Legal Assistance and Access to Justice in Indonesia, makalah dalam First International Colloquium on Legal Aid and Legal Service, 25-28 Oktober 1976 (London-England: International Committee Law Exchange Society 1976/ 1977), hlm. 1.

${ }_{20}$ Juhaya S. Praja, Filsafat Hukum Islam. hlm. 46. dilarang menerapkan hukum-hukum lainnya yang bertentangan dengan hukum Allah itu. Ketentuan ini salah satunya tercantum dalam QS. al-Mâidah: 48-49.

3. Prinsip Kebebasan/al-hurriyyah Menurut prinsip ini, manusia memiliki hak/kebebasan dalam hal menen-tukan pilihan hidupnya, tetapi hak/kebebasan itu tidak bertentangan dengan apa-apa yang telah digariskan oleh Allah dan rasulNya. Ketentuan ini salah satunya tercantum dalam QS. al-Baqarah: 256.

4. Prinsip Persamaan/al-musâwah Menurut prinsip ini, fitrah manusia sebagai makhluk Allah yang diciptakan-Nya menjadi berpasang-pasangan, bersukusuku dan berbangsa-bangsa. Kedudukan manusia sama di mata Allah adalah sama, dan yang paling tinggi derajatnya adalah orang yang bertakwa. Ketentuan ini salah satunya tercantum dalam QS. al-Hujurât: 13.

5. Prinsip Menyeru Kepada Kebaikan dan Melarang Kemunkaran/'amar ma'ruf nahyi munkar

Menurut prinsip ini, manusia memiliki kewajiban untuk tunduk kepada hukumhukum Allah, menyeru kepada yang baik dan mencegah dari yang munkar. Ketentuan ini salah satunya tercantum dalam QS. al-Nisâ': 114.

6. Prinsip Tolong-menolong/al-ta‘âwun Menurut prinsip ini, manusia berkewajiban untuk saling tolong-menolong dalam kebaikan dan dilarang tolong-menolong dalam keburukan. Ketentuan ini salah satunya tercantum dalam QS. al-Mâidah: 2.

7. Prinsip Hak Allah dan Hak Manusia Menurut prinsip ini, manusia diberikan hak/kebebasan untuk melaksanakan hukum Allah pada batas-batas kewajaran yang telah ditentukan oleh Allah. Ketentuan ini salah satunya tercantum dalam QS. 2 : 178.

8. Prinsip Musyawarah untuk Mufakat/almusyawarah

Menurut prinsip ini, manusia berkewajiban untuk saling bermusyawarah untuk mufakat dalam menyelesaikan berbagai urusan. Ketentuan ini salah satunya tercantum dalam QS. al-Zukhruf: 38. 
9. Prinsip Toleransi/al-tasâmuh

Menurut prinsip ini, manusia berkewajiban bersikap toleran dalam menghargai perbedaan keyakinan dan agama serta memiliki hak/kebebasan untuk memilihnya berdasarkan keyakinan masingmasing. Ketentuan ini salah satunya tercantum dalam QS. al-Kâfirûn: 1-6.

Di samping itu, ada beberapa asas-asas hukum Islam yang erat kaitannya dengan penegakan hukum di pengadilan, antara lain:

1. Asas Kehormatan Manusia

Menurut asas ini, manusia memiliki kehormatan yang diberikan Allah dengan hakhak yang dimilikinya. Salah satunya tercantum dalam QS. al-Baqarah: 30.

2. Asas Penaatan Hukum

Menurut asas ini, manusia memiliki kewajiban untuk tunduk, taat dan patuh kepada hukum-hukum Allah dan rasul-Nya. Salah satunya tercantum dalam QS. alAnfâl: 20.

3. Asas Kekeluargaan dan Kemanusiaan Menurut asas ini, manusia memiliki harkat dan martabat yang sama di sisi Allah serta kemulian karena ketakwaannya. Salah satunya tercantum dalam QS. al-Hujurât: 13.

4. Asas Gotong-royong dalam Kebaikan Menurut asas ini, manusia berkewajiban untuk berlomba-lomba dalam berbuat kebaikan dan takwa sesuai dengan kemampuannya. Salah satunya tercantum dalam QS. al-Mâidah: 2.

5. Asas Keadilan, Kelayakan dan Kebaikan Menurut asas ini, manusia berkewajiban berlaku adil dan berbuat baik antar sesama manusia serta dilarang untuk saling berselisih. Salah satunya tercantum dalam QS. al-Nahl: 90.

6. Asas Menarik Manfaat dan Menghindari Madarat

Menurut asas ini, manusia berkewajiban menjauhi segala perbuatan yang dapat mengakibatkan kemadaratan bagi dirinya. Salah satunya tercantum dalam QS. alMâidah: 105.

7. Asas Kebebasan dan Kehendak

Menurut asas ini, manusia memiliki hak/kebebasan untuk berbuat tetapi dibatasi oleh kewajiban untuk tunduk, taat dan patuh kepada hukum-hukum Allah dan
rasul-Nya. Salah satunya tercantum dalam QS. al-Anfâl: 24.

8. Asas Kesukarelaan

Menurut asas ini, manusia memiliki hak/kebebasan untuk memiliki sesuatu dengan cara suka sama suka (sukarela) dengan tidak melanggar hukum-hukum Allah dan rasul-Nya. Salah satunya tercantum dalam QS. al-Nisâ': 29.

Berdasarkan prinsip-prinsip dan asasasas itulah, maka penegakan hukum di pengadilan hendaknya ditujukan untuk keadilan, kebaikan dan kemaslahatan bagi manusia itu sendiri. Oleh karena itu, dapat dikatakan di sini bahwa prinsip-prinsip, asas-asas dan tujuan penegakan hukum dalam perspektif hukum Islam, tidak semata-mata didasarkan kepada kewajiban melaksanakan syariat itu sendiri, melainkan yang paling utama adalah bagaimana menegakan keadilan di tengahtengah masyarakat dengan tidak mengabaikan syariat sebagai hukum yang mengikat bagi orang Islam. Dengan kata lain, meskipun ide dasar adanya bantuan hukum (legal aid atau legal service) dalam proses upaya hukum di pengadilan ditujukan untuk mendapatkan keadilan bagi semua subyek hukum, tetapi kita tidak dibenarkan mengabaikan prinsip-prinsip, asas-asas dan tujuan syariat Islam itu sendiri.

\section{F. Teori-teori Bantuan Hukum dan Kepe- ngacaraan dalam Hukum Islam}

Apabila diruntut dari rentang waktu perkembangan lahirnya, ilmu tafsir ahkam memberikan sumbangan luar biasa bagi pengembangan teori-teori bantuan hukum dalam hukum Islam. Teori-teori penegakan hukum Islam yang berkembang dari penafsiran ayat-ayat hukum menjadi dasar bagi penemuan konsep bantuan hukum yang berlangsung selama tiga periode yakni klasik, pertengahan dan modern.

Pertama, Periode Klasik. Periode Klasik yang dimaksud di sini adalah fase awal pembentukan dasar-dasar teori penegakan hukum. Dalam hal ini penulis membatasi pelacakan tentang teori penegakan hukum kepada dua bagian, yakni pembentukan teori hukum Islam di masa Rasul.

Untuk melacak teori-teori penegakan hukum Islam pada periode kerasulan 
Muhammad SAW bukanlah hal yang mudah, tetapi penulis akan berupaya melacaknya dari beberapa keterangan hadits dan peristiwa hukum yang terjadi pada masa rasul.

1. Teori Pengakuan

Dalam suatu hadits diceritakan bahwa ada seorang wanita Ghamidiyah menghadap Rasul dan mengaku telah berzina. Beberapa kali ia mengaku perbuatannya kepada Rasul sampai ia melahirkan dan anaknya disapih. Kemudian wanita itu datang lagi kepada Rasul dan meminta untuk membersihkan diri dari dosa zinanya. Atas pengakuan tersebut, Rasulpun menjatuhkan hukuman rajam. ${ }^{21}$

\section{Teori Persaksian}

Kesaksian merupakan salah satu syarat dalam proses penegakan hukum. Dalam al-Quran dinyatakan: "Dan persaksikanlah dengan dua orang saksi dari orang-orang lelaki diantaramu. Jika tak ada dua orang lelaki, maka (boleh) seorang lelaki dan dua orang perempuan". ${ }^{22}$ Kemudian dipertegas pula dalam hadits nabi bahwa "Dua saksi dari kalian, atau sumpahnya". Dalam riwayat lainnya, Ibnu Qudâmah mengatakan: "Saksi boleh melihat terdakwa supaya persaksiannya tidak salah alamat. Imâm Ahmad berkata: Tidak boleh memberikan persaksian terhadap seorang terdakwa wanita hingga ia mengenali indentitasnya dengan pasti".

3. Teori Pembuktian

Dalam peradilan Islam, sistem pembuktiannya didasarkan kepada prinsip kejelasan dan menghindari kesamaran. Seorang hakim tidak boleh memutuskan perkara ketika tidak ada alat bukti. Imam Baihaki telah meriwayatkan sebuah hadits dengan isnad shahih dari Nabi SAW, sesungguhnya Rasulullah SAW bersabda: "Bukti itu wajib bagi orang yang men-

\footnotetext{
${ }^{21}$ Rajam adalah suatu bentuk hukuman mati yang diberikan kepada laki-laki atau perempuan dewasa yang telah menikah dan melakukan dosa zina. Larangan zina tegas dilarang dalam QS. al-Isrâ' ayat 32, di mana pelakunya wajib dirajam setelah melalui proses pembuktian berupa adanya saksi-saksi dan pengakuan dari orang yang telah melakukannya. Kasus dalam hadits di atas menjadi dasar bagi adanya teori pengakuan dalam penegakan hukum Islam.

22 QS. al-Baqarah ayat 282.
}

dakwa, sedangkan sumpah itu wajib bagi orang yang mengingkarinya”. Sesuatu tidak bisa menjadi bukti, kecuali jika sesuatu itu meyakinkan dan pasti. Seseorang tidak boleh memberikan kesaksian terkecuali kesaksiannya itu didasarkan pada sesuatu yang menyakinkan. Atas dasar itu, salah satu pembuktian menjadi dasar teori penegakan hukum dalam sistem lembaga peradilan Islam.

4. Teori Putusan

Dalam QS. al-Nisâ': 58-59 dijelaskan bahwa setiap orang (hakim) diharuskan memutus perkara dengan cara yang adil. ${ }^{23}$ Dipertegas pula dalam hadits Rasulullah SAW bahwa: "Janganlah kamu memutuskan perkara dalam keadaan marah". Berdasarkan kedua teks tersebut, setiap orang (aparat penegak hukum) diharuskan berlaku adil dalam menetapkan putusan hukum. Ini menjadi dasar adanya teori putusan dalam sistem peradilan Islam.

5. Teori Sumpah

Sumpah telah ditetapkan dalilnya baik di dalam al-Quran maupun Sunnah. Allah SWT berfirman: "Allah tidak menghukum kamu disebabkan sumpah-sumpahmu yang tidak dimaksud (untuk bersumpah), tetapi Dia menghukum kamu disebabkan sumpah-sumpah yang kamu sengaja, maka kafarat (melanggar) sumpah itu ialah memberi makan sepuluh orang miskin, yaitu dari makanan yang biasa kamu berikan kepada keluargamu, atau memberi pakaian kepada mereka, atau memerdekakan seorang budak. Barangsiapa tidak sanggup melakukan yang demikian, maka kaffaratnya puasa selama tiga hari. Yang demikian itu adalah kaffarat sumpah-sumpahmu bila kamu bersumpah (dan kamu langgar)". ${ }^{24}$ Kemudian dipertegas oleh Rasulullah SAW yang bersabda bahwa: "Bukti itu wajib bagi orang yang mendakwa sedangkan sumpah itu wajib bagi orang yang mengingkarinya”. Kedua teks tersebut menjadi dasar adanya teori sumpah dalam sistem peradilan Islam.

6. Teori Pengampunan

23 QS. al-Mâidah ayat 58-59.

24 QS. al-Mâidah ayat 89. 
Dalam QS. al-Baqarah: 178 Allah menyatakan: "Hai orang-orang yang beriman, diwajibkan ke atas kamu qishash berkenaan dengan orang-orang yang dibunuh; orang merdeka dengan orang merdeka; hamba dengan hamba dan wanita dengan wanita. Maka barangsiapa yang mendapat kemaafan dari saudaranya, hendaklah (yang memaafkan) mengikuti dengan cara yang baik, dan hendaklah (yang diberi maaf) membayar diyat kepada pemberi maaf dengan cara yang baik pula".

Kedua, Periode Pertengahan. Periode Pertengahan yang dimaksud di sini adalah fase pengembangan teori-teori penegakan hukum pada institusi hukum. Dalam hal ini penulis membatasi pelacakan teori penegakan hukum kepada dua bagian, yakni pengembangan teori penegakan hukum Islam di masa khilafah dan pengem-bangan teori-teori penegakan hukum di dunia Barat mulai dari abad kegelapan (the dark age) sampai abad pencerahan (the englightenment age).

Untuk melacak teori-teori penegakan hukum pada masa khilafah, penulis berupaya melacaknya dari beberapa literatur yang menjelaskan pemikiran para ahli hukum atau kasus-kasus penyelesaian hukum yang terjadi di masa khilafah.

1. Teori Perjanjian/Sumpah (Bay'at)

Dalam suatu hadits disebutkan bahwa Rasulullah SAW bersabda: "Barang-siapa membaiat seorang Imâm (khalifah), lalu memberikan genggaman tangannya dan menyerahkan buah hatinya, hendaklah ia mentaatinya semaksima mungkin. Dan jika datang orang lain hendak mencabut kekuasaannya, penggallah leher orang itu". Dalam hadits lainnya juga dijelaskan bahwa Rasulullah SAW bersabda: "Jika dibaiat dua orang Khalifah, maka bunuhlah yang terakhir dari keduanya". Dari kedua hadits ini, proses penyelesaian perkara di depan pengadilan salah satunya dilakukan melalui sumpah atau baiat. Baiat tersebut dipraktekan bukan hanya dalam proses pengambilan sumpah jabatan dari rakyat kepada pemimpinnya, atau dari pimpinan yang lebih tinggi kepada bawahannya, tetapi juga dari seorang hakim kepada saksi atau pelaku tindak pelang- garan hukum. Baiat ini terjadi pada masa awal Khulafâ' al-Râsyidin sampai runtuhnya kekuasaan dinasti Utsmani di Turki. Baiat atau sumpah menjadi dasar bagi adanya teori pembuktian hukum.

2. Teori Musyawarah (Syurâ')

Dalam sejarah awal politik hukum Islam, banyak ditemukan mekanisme penyelesaian perkara melalui syurâ'. Dalam konteks ini, istilah syurâ' awalnya diketahui ketika para sahabat Rasul melakukan musyawarah di Tsaqifah bani Saydah untuk memilih pemimpin sepeninggalnya Rasulullah SAW. Fakta sejarah awal menunjukkan bahwa mereka bersepakat mengangkat Abû Bakar al-Shiddiq sebagai khalifah pertama pengganti kepemimpinan Rasul. ${ }^{25}$ Dalam perkembangannya, syurâ' tidak hanya berlaku dalam bidang politik, tetapi juga berlaku pula dalam bidang penegakan hukum berupa penyelesaian sengketa hukum di luar pengadilan sebagaimana kita kenal sekarang dengan istilah non-litigasi.

3. Teori Perdamaian/Arbitrase (Tahkîm) Memasuki fase akhir Khulafâ' al-Râsyidin, pernah terjadi Perang Sipil pertama (Perang Shiffin) antara 'Alî bin Abî Thalib dengan Mu'âwiyah bin Abî Sufyân. Peperangan itu berhenti setelah terjadinya gencatan senjata melalui proses arbitrase (al-Tahkîm) antara kelompok 'Alî bin Abî Thalib yang diwakili oleh Abî Mûsâ alAsy'arî dan kelompok Mu'âwiyah bin Abî Sufyân yang diwakili oleh 'Amr bin 'Ash. Arbitrase (al-Tahkîm) itu dapat dilihat sebagai salah satu bentuk prosedur dalam proses pendelegasian wewenang atau pengambilan keputusan baik di bidang politik maupun hukum. ${ }^{26}$ Meski demikian, kasus itu memberi sinyalemen bahwa

25 Fred M. Donner, dalam bukunya The Early Islamic Conquests (1981) menyebutkan bahwa justru kebiasaan bangsa Arab ketika itu adalah untuk mengumpulkan para tokoh masyarakat dari suatu keluarga (bani dalam bahasa arab), atau suku, untuk bermusyawarah dan memilih pemimpin dari salah satu diantara mereka. Tidak ada prosedur spesifik dalam syurâ' atau musyâwarah ini. Lihat dalam http://id.wikipedia.org/wiki/Khalifah.

26 Rosihon Anwar (Penerjemah), Meluruskan Sejarah Islam: Studi Kritis Peristiwa Tahkim (Bandung: Pustaka Setia. 1999), hlm. 69. 
arbitrase (al-Tahkîm) menjadi salah satu cara/alat untuk melakukan proses penyelesaian hukum baik di dalam pengadilan (litigasi) maupun di luar pengadilan (non-litigasi). Tahkîm inipun dapat menjadi dasar bagi adanya teori penyelesaian hukum di dalam maupun di luar pengadilan.

4. Teori Konsensus (ijma')

Konsep ijma' dalam pemikiran hukum Islam bisa dikatakan sebagai konsep hukum yang revolusioner. Betapa tidak, sebab sumber-sumber hukum yang sebelumnya hanya mengacu kepada al-Quran dan Sunnah, lalu dalam perjalanan sejarahnya, membuktikan bahwa terdapat otoritas selain al-Quran dan Sunnah, yaitu ijma ${ }^{6 .}$

5. Teori Analogi (Qiyas) Imâm Syâfi'î dalam al-Risâlah menyatakan: "Barangsiapa berpendapat sesuai dengan pandangan kebanyakan komunitas muslim, sesungguhnya ia telah menunaikan konsensus (ijma'). Sebaliknya, barang siapa bertolak belakang dengan pandangan kebanyakan komunitas muslim, sesungguhnya ia telah melanggar konsensus. Kelalaian hanya terjadi dalam keterpecahan dalam mencapai konsensus. Sedangkan konsensus tidak akan melahirkan kelalain terhadap makna al-Quran, Sunnah dan Qiyas (Analogi)”. Pandangan Imâm al-Syâfi'î tersebut menjadi dasar penyelesaian hukum yang ketentuannya tidak diatur jelas dalam nash, maka diselesaikan dengan ijma' (konsensus) dan qiyas (analogi). Hal ini menjadi dasar pula bagi penyelesaian kasus-kasus sengketa hukum yang bersifat ijtihadi pada zaman berikutnya. ${ }^{28}$

Ketiga, Periode Modern. Periode Modern yang dimaksud di sini adalah fase pengembangan teori-teori penegakan hu-

27 Ibnu Hazm, al-Muhallâ (Kairo: Dâr al-Maktab. t.th.), hlm. 128.

28 Penggunaan ijma' dan qiyas oleh Imâm Syâfîî dalam menyelesaikan kasus-kasus hukum lebih didominasi oleh pertimbangan rasionalitas dan relaitas hukum Islam dalam masyarakat muslim. Lihat penjelasan Zuhairi Misrawi, "Konsep ljma' Sebagai Partisipasi Otonom" dalam http://islamlib. com/id/index.php?page=article\&id=567, diakses tanggal o2 Februari 2015. kum dalam institusi-institusi hukum modern berikut keterkaitannya dengan hukum konstitusi dan hukum internasional. Dalam konteks ini, penulis membatasi pelacakan teori penegakan hukum di institusi-institusi hukum menjadi dua bagian, yakni pengembangan teori penegakan hukum Islam dalam peradilan Islam pada pasca khilafah.

Untuk melacak teori-teori penegakan hukum pada periode modern, penulis berupaya melacaknya dari beberapa literatur yang menjelaskan pemikiran para pemikir hukum Islam atau kasus-kasus penyelesaian hukum yang terjadi pada masa pasca khilafah (sejak keruntuhan Dinasti Turki Utsmani dan era kolonialisasi serta pembentukan negara hukum modern di sejumlah negaranegara muslim). ${ }^{29}$

29 Penulis melakukan telaah histotis teori-teori penegakan hukum pada periode pasca Khilafah dimulai dari keruntuhan Dinasti Turki Utsmani di Turki pada 3 Maret 1924 sampai dengan periode negara hukum modern atau sampai berakhirnya era Kolonialisme Barat terhadap Negara-negara Muslim. Tercatat dalam sejarah Islam bahwa kekuasaan Turki Utsmani terdiri dari empat fase: (a) Kebangkitan kesultanan (12991453); (b) pengembangan wilayah dan puncak keemasan (1453-1566); (c) pemberontakan dan kebangkitan kembali (1566-1683) dan (d) fase kemunduran dan keruntuhan (1683-1924). Ada 3 sebab yang menjadikan kekhilafahan Turki Utsmani runtuh: (a) buruknya pemahaman Islam; (b) kekeliruan dalam melaksanakan hukum Islam; dan (c) masuknya propaganda dan misionaris Kristen Barat ke dalam tatanan sosial, ekonomi, politik, hukum dan budaya masyarakat muslim saat itu. Masa-masa keemasan Turki Utsmani berlangsung pada abad ke-16 dan 17 yang diikuti keruntuhannya bersamaan dengan era kebangkitan di dunia Barat (the enlightenment age) pada akhir abad ke-18. Awal keruntuhan Turki Utsmani terjadi pada masa kekhalifahan Abdul Madjid II yakni ia telah mengubah sistem pemerintahan dan hukum Islam dengan sistem pemerintahan Barat dan hukum Eropa. Kampanye mulai dilakukan Rasyid Pasha (Menlu zaman Sultan Abdul Mejid II) tahun 1839. Tahun itu juga, Naskah Terhormat (Kholkhonah) - yang dijiplak dari undang-undang di Eropa diberlakukan resmi. Tahun 1855, negara-negara Eropa - khususnya Inggris - memaksa khilafah Utsmani untuk mengamandemen Undang-Undang Dasar, sehingga dikeluarkanlah Naskah Hemayun pada 11 Februari 1855 . Midhat Pasha, salah satu anggota Kebatinan Bebas diangkat jadi perdana menteri (1 September 1876). la membentuk panitia Ad Hoc menyusun UUD menurut Konstitusi Belgia. Inilah yang dikenal dengan Konstitusi 1876. Namun, konstitusi ini ditolak oleh Sultan Abdul Hamid II dan Sublime Port-pun enggan melaksanakannya karena dinilai bertentangan dengan 
1. Teori Persamaan Hak-Shubhî Mahmashânî Shubhî Mahmashânî dikenal sebagai salah seorang pemikir Islam dari Mesir yang banyak menjelaskan tentang HAM dalam bukunya Huqûq al-Insân fî al-Islâm. Menurutnya, konsep HAM dalam Islam didasarkan pada kesetaraan hak dan kewajiban antara sesama manusia. Konsep ini berpijak secara normatif pada prinsip persamaan (al-Musâwah) dan kebebasan (al-hurriuyah) dalam norma-norma syariat bahwa asas paling fundamental tentang harkat dan martabat kemanusiaan lebih didasarkan kepada pemenuhan hak dan kewajiban yang melekat pada setiap manusia dengan tanpa diskriminasi ras, suku, warna kulit, bahasa, jenis kelamin, keyakinan dan agama, sikap politik, status sosial dan lain-lain. Teori persamaan hak ini menjadi dasar bagi perumusan konsep bantuan hukum dalam hukum Islam. ${ }^{30}$

syariat. Midhat Pashapun dipecat dari kedudukan perdana menteri. Turki Muda yang berpusat di Salonika (pusat komunitas Yahudi Dunamah) memberontak tahun 1908. Khalifah dipaksanya menjalankan keputusan Konferensi Berlin - mengumumkan UUD baru yang dibuat oleh Turki Muda di Salonika, lalu dibukukanlah parlemen yang pertama dalam khilafah Turki Utsmani (17 November 1908). Bekerja sama dengan syaikhul Islam, Sultan Abdul Hamid II dipecat dari jabatannya, dan dibuang ke Salonika. Sejak saat itulah, praktis secara konstitusional, sistem pemerintahan Islam berakhir dan diperparah dengan terjadinya Perang Dunia I tahun 1914. Momentum tersebut digunakan Inggris untuk menghancurkan Turki dari dalam yakni dengan cara memanfaatkan pengaruh Mustafa Kemal Pasha alTaturk melalui kekuasaan militer Turki untuk mengambil alih kekuasaan khilafah dan menggantinya dengan sistem demokrasi sekuler pada 3 Maret 1924. Namun seiring dengan keruntuhan Turki Utsmani, di belahan dunia Islam yang lain muncul gerakan Pan-Islamisme oleh al-Afghani, Ikhwanul Muslimin oleh Hassan alBana, Harakah al-Tajdid oleh Muh. Abduh di Mesir dan Muh. Bin Abdul Wahhab di Saudi Arabia, serta Syarikat Islam oleh H.O.S. Tjokroaminoto di Indonesia. Lihat sejarah lengkap dalam Nadiyah Mahmud Musthafâ, al'Ashrul 'Utsmâni minal Quwwatul Haymanah illâ Bidâyah al-Mas'alat al-Syarqiyyah. Istanbul: Al-Ma'hadul 'Alami lil Fikrul Islami. 1996), hlm. 94. Ali Mufradi, Kerajaan Utsmani dalam Ensiklopedi Tematis Dunia Islam (Jakarta: PT. Ichtiar Baru van Hoeve. 2002), hlm. 236-246 dan Ali Muhammad Asy-Syalabi, Bangkit dan Runtuhnya Khilafah 'Utsmaniyah (Jakarta: Pustaka Al-Kautsar. 2003), hlm. 403-425.

30 Shubhî Mahmashânî, Huqûq al-Insân fî al-Islâm (Cairo: Dâr al-Maktabah. t.th.) dan J.J. Donohue and
2. Teori Justifikasi - Riffat Hassan

Riffat Hassan dikenal sebagai salah seorang pemikir Islam modern dari Mesir yang juga banyak menjelaskan tentang HAM dalam tulisannya On Human Rights and the Quranic Perspective. Menurutnya, hukum Islam sangat ketat mengatur masalah hukum, termasuk batasan tentang hak dan kewajiban dalam al-Quran. Prinsip-prinsip dasar hukum Islam dalam al-Quran cenderung bersifat doktrinal dan monoteistik, di mana otoritas pembuat hukum mutlak berada di tangan Allah, sementara manusia yang diberi kelebihan (para faqih) pun hanya memiliki wewenang yang sangat terbatas pada segi otoritas kemanusiaannya. ${ }^{31}$

3. Teori Penegakan Hukum - 'Abdullah Ahmad al-Na'îm

'Abdullah Ahmad al-Na'îm" 32 dikenal sebagai salah seorang pemikir Islam dari Sudan yang juga banyak menjelaskan ten-

John L. Esposito, eds., Islam in Transition: Muslim Perspectives (Oxford: Oxford University Press. 1982), hlm. 181-187.

31 Riffat Hassan menjelaskan bahwa: "In the light of the Islamic warning that the transcendence of the divine creator must never be amalgamated with His creation. He argues that the invocation of God as a pretext to legitimize earthly power relations must be rejected as a violation of Islam. In particular she attacks the traditional hierarchy between the genders which has often provided the husband with almost a quasi-divine authority. According to him, this religious justification of social authority borders on blasphemy. She thus points out sarcastically: "The husband, in fact, is regarded as his wife's gateway to heaven or hell and the arbiter of her final destiny. That such an idea can exist within the framework of Islam -- which totally rejects the idea of redemption, of any intermediary between a believer and the Creator -- represents both a profound irony and a great tragedy." His argumentation demonstrates that the Islamic doctrine of strict monotheism, a doctrine from which fundamentalist authors like Mawdudi derive authoritarian political consequences, can also be understood in an emancipatory sense in that monotheism provides a theological basis for challenging absolute power relations between human beings. Lihat tulisan Rifaat Hassan, "On Human Rights and the Qur'anic Perspective," in: Arlene Swidler, ed., Human Rights in Religious Traditions (New York: The Pilgrim Press. 1982), hlm. 51-65.

32 Review atas tulisan 'Abdullah Ahmad alNâ'im, Towards an Islamic Reformation: Civil Liberties, Human Rights and International Law (Syracuse: Syracuce University Press. 1994). 
tang HAM dalam bukunya Towards an Islamic Reformation: Civil Liberties, Human Rights and Constitutional Law. Menurutnya, hukum Islam berkembang hingga saat ini adalah syariat produk sejarah, hasil pemikiran ulama terdahulu, produk kekuasaan politik Islam dan banyak mengabaikan segi-segi perubahan hukum dan HAM di dunia modern. Oleh karena itu, Pemberlakuan hukum Islam menurutnya dilakukan dengan tiga metode: (1) Penafsiran teks-teks hukum Islam hendaknya berpijak pada perubahan hukum berlatar teori nasikh-mansukh, seperti keberlakukan syariat pada periode Makkah dan Madinah, baik secara tekstual maupun kontekstual; (2) Perubahan hukum Islam hendaknya dilakukan secara gradual dan dialektis serta mempertimbangkan aspekaspek sosiologis dan antropologis; (3) Umat Islam juga hendaknya mau merubah paradigma berpikir eklusif menjadi inklusif, yakni terbuka dalam menerima tradisi dan budaya lainnya dengan berpedoman kepada asas resiprositas, yakni "seseorang harus menghargai hak dan kewajiban orang lain dan orang lainpun harus melakukan hal yang sama"; (4) Rekonsiliasi Hukum Islam dan HAM hanya dapat dilakukan dalam konteks pengakuan dan kesadaran kolektif yang berpijak kepada asas relativitas budaya (cultural relativism), pertukaran budaya (crossculture) dan hak menentukan nasib sendiri (self determination); (5) Aplikasi hukum Islam (the application of sharia), agar tidak berbenturan dengan standar HAM universal, hendaknya dituangkan ke dalam konstitusi negara dan konvensi internasional melalui proses politik yang demokratis. Konsep ini, teori persamaan hak ini menjadi dasar bagi perumusan konsep bantuan hukum dalam hukum Islam.

\section{G. Penutup}

Mengacu kepada pembahasan di atas, penulis dapat menyimpulkan bahwa perumusan prinsip-prinsip dan asas-asas bantuan hukum berikut kepengacaraan dalam hukum Islam terbukti tidak lepas dari teori-teori penegakan hukum dan tujuan hukum Islam. Dalam banyak aspek, penegakan hukum juga bukan hanya dibebankan kepada hakim di pengadilan, namun juga kepada pengacara (advokat) dalam lingkup mediasi di dalam dan luar pengadilan.

Khusus bagi hakim, dalam merumuskan pertimbangan-pertimbangan hukumnya ia akan selalu terikat dengan peran dan tugasnya sebagai penegak hukum di pengadilan. Setiap hakim hendaknya turut mendorong peran pengacara dan bantuan hukum dalam proses penegakan hukum. Mediasi melalui pengacara atau advokat adalah langkah awal penegakan hukum sebelum ke pengadikan. Sedangkan lembaga pengadilan hanyalah upaya hukum terakhir bagi para pihak untuk memperoleh keadilan.

Perumusan prinsio-prinsip dan asas-asas kepengacaraan dan bantuan hukum dalam direduksi dari tafsir al-Quran surat al-Nisâ' ayat 35, terbukti telah memberikan sumbangan bagi pengembangan teori-teori penegakan hukum dalam struktur keilmuan hukum Islam. Lebih dari itu, pengembangan teori-teori penegakan hukum yang merujuk kepada al-Quran terbukti lebih memiliki semangat yang memadukan spiritualitas dan formalisme penegakan hukum.

\section{Daftar Pustaka}

Anwar, Rosihon (Penerjemah). 1999. Meluruskan Sejarah Islam: Studi Kritis Peristiwa Tahkim. Bandung: Pustaka Setia.

Avineri, Shlomo. 1968. The Social and Political Thought of Karl Marx. t.t.: Cambridge University Press.

Barnett, Helaine M. 2005. Documenting the Justice Gap in America: The Current Unmet Civil Legal Needs of Low-Income Americans. USA: Legal Services Corporation.

Berlin, Isaiah. 1963. Karl Marx: His Life and Environment. Britania: Oxford University Press.

Cohen, G. A. 1978. Karl Marx's Theory of History: A Defence. t.t.: Princeton University Press.

Djamil, Fathurrahman. 1997. Filsafat Hukum Islam. Jakarta: Logos Wacana Ilmu. 
Donohue, J.J. and John L. Esposito, eds. 1982. Islam in Transition: Muslim Perspectives. Oxford: Oxford University Press.

Hazm, Ibnu, t.th. al-Muhallâ. Kairo: Dâr alMaktab.

Houseman, Alan W. \& Linda E. Perle. 2003. Securing Equal Justice for All: A Brief History of Civil Legal Assistance in the United States. US: Center for Law and Social Policy.

Jawziyyah, Ibnu Qayyim al-. t.th. I'lâm alMuwaqqiînn. Beirut: Dâr al-Fikr.

Kelsen, Hans. 2005. Pure Theory of Law. t.t.: Lawbook Exchange Ltd.

Khidr, Muhammad. 1980. al-Islâm wa Huqûq al-Insân. Beirut: Dâr al-Maktabah alHayat.

Mahmashânî, Shubhî. t.th. Huqûq al-Insân fî al-Islâm. Cairo: Dâr al-Maktabah.

Mahyudi, Imam (Penerjemah). 1996. Hak Asasi Manusia Dalam Islam. Jakarta: Rajawali Press.

Mawdûdî, Abû al-A'lâ al-. 1976. Human Rights in Islam. Leicester: The Islamic Foundation.

Mufradi, Ali. 2002. Kerajaan Utsmani dalam Ensiklopedi Tematis Dunia Islam. Jakarta: PT. Ichtiar Baru van Hoeve.

Mûsâ, Yûsuf. t.th. Târîkh al-Figh al-Islâmî. Beirut: Dâr al-Maktabah al-Hayat.

Muslehudin, Muhammad. 1992. Filsafat Hukum Islam dan Pemikiran Orientalis (terj. Yudian Wahyudi Asmin). Yogyakarta: Tiara Wacana.

Musthafâ, Nadiyah Mahmud. 1996. al-‘Ashrul 'Utsmâni minal Quwwatul Haymanah illâ Bidâyah al-Mas'alat al-Syarqiyyah. Istanbul: Al-Ma'hadul 'Alami lil Fikrul Islami.

Nâ'im, 'Abdullah Ahmad al-. 1994. Towards an Islamic Reformation: Civil Liberties, Human Rights and International Law. Syracuse: Syracuce University Press.

Nabî, 'Ali Jâr al-. al-Mahammah wa Afâqa alQanûni fî al-Mustaqbal dalam http;//- www.brbrnet.net/vb/archive/index.php/ t-2106.html, diakses tanggal 28 Januari 2015.

Poerwadarminta, W.J.S. 1992. Kamus Besar Bahasa Indonesia. Jakarta: PT. Ghalia Indonesia.

Praja, Juhaya S. 1996. Filsafat Hukum Islam. Bandung: UNISBA Press.

Qaththân, Mannâ' al-. t.th. al-Tasyrî wa al-Fiqh fî al-Islâm. Cairo: Mu'assasah al-Risâlah.

Rahman, Asjmuni. 1976. Kaidah-kaidah Fiqih (Qawa'id al-Fiqhiyyah). Jakarta: Bulan Bintang.

Reiter, Allan C. 2002. Democracies at War. Princeton, USA: Princeton University Press.

Salâm, 'Izzu al-Dîn bin 'Abd al-. t.th. Qawâ'id al-Ahkâm fî al-Mashâlih al-Anâm. Beirut: Dâr al-Fikr.

Santosa, Mas Achmad. 2007. Perjalanan ke Depan Bantuan Hukum dan Access to Justice dalam Bantuan Hukum di Indonesia: Akses Masyarakat Marjinal Terhadap Keadilan (Ed. Gatot dan Virza). Jakarta: LBH Jakarta.

Summers, Robert S. 1982. Instrumentalism and American Legal Theory. Ithaca, NY: Cornell University Press.

Syalabi, Ali Muhammad Asy-. 2003. Bangkit dan Runtuhnya Khilafah 'Utsmaniyah. Jakarta: Pustaka Al-Kautsar.

Syâthibî, Abû Ishak al-. t.th. al-Muwâfaqât fi Ushûl al-Syarî‘ah. Beirut: Dâr al-Kutûb al'Ilmiyyah.

Undang-Undang Nomor 18 Tahun 2003 tentang Advokat.

Usman, Mukhlish. 2000. Kaidah-kaidah Ushuliyah dan Fiqhiyyah. Jakarta: Gema Insani Press.

Usman, Mukhlish. 2000. Kaidah-kaidah Ushuliyah dan Fiqhiyyah. Jakarta: Gema Insani Press.

Zaydan, 'Abd al-Karîm. 1983. Nizhâm al-Qadlâ' fî al-Syarî́at al-Islâmiyyah. Baghdad: Matba'ah al-‘Ayni. 